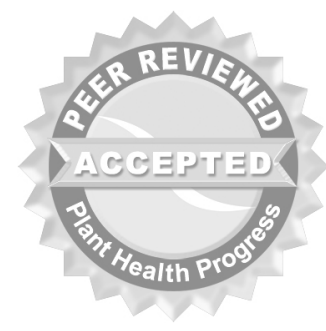

(c) 2009 Plant Management Network.

Accepted for publication 18 September 2009. Published 4 December 2009.

\title{
First Report of Soillborne wheat mosaic virus on Triticum aestivum in Washington State
}

T. D. Murray, Professor, and H. R. Pappu, Associate Professor and Chair, Department of Plant Pathology, Washington State University, Pullman, WA 99164-6430; and R. W. Smiley, Professor of Plant Pathology, Oregon State University, Columbia Basin Agricultural Research Center, Pendleton, OR 97801-0370

Corresponding author: T. D. Murray.tim_murray@wsu.edu

Murray, T. D., Pappu, H. R., and Smiley, R. W. 2009. First report of Soilborne wheat mosaic virus on Triticum aestivum in Washington State. Online. Plant Health Progress doi: 10.1094/PHP-2009-1204-01-BR.

Wheat soilborne mosaic (WSBM) was first discovered in the central plains of the USA in 1919 and, by 1923, Soilborne wheat mosaic virus (SBWMV) was identified as the cause. SBWMV is vectored by the soilborne plasmodiophorid, Polymyxa graminis.

Symptoms of WSBM range from a mild green to yellow mosaic on the leaves. Symptoms are most apparent on early-spring growth and seldom appear in autumn. Within fields, disease may be uniform but is often found in patches reflecting distribution of its soilborne vector (Fig. 1). New leaves and leaf sheaths of infected plants appear mottled and develop dashes and streaks parallel to the veins. Rising temperatures in spring slow and eventually stop symptom development. WSBM is a disease primarily of autumn-sown wheat, although spring wheat is susceptible. Yield loss varies with cultivar, virus strain, and environment and range from minor to entire fields.

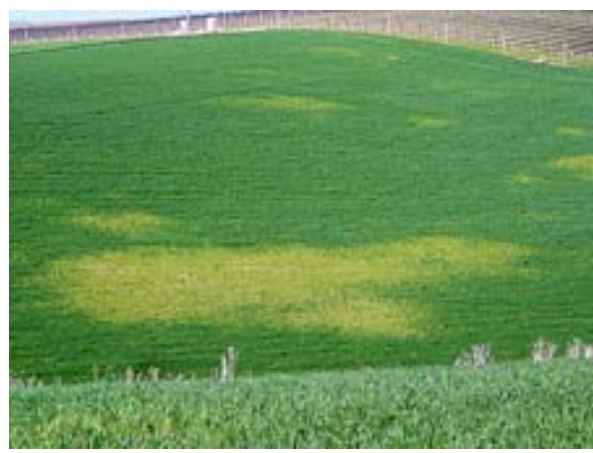

Fig. 1. Winter wheat field near Walla Walla, WA, with yellowish patches of stunted wheat where Soilborne wheat mosaic virus was found. 


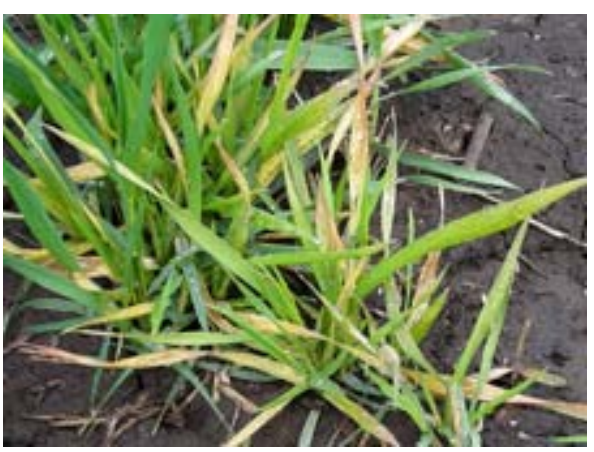

Fig. 2. Stunting and mosaic of wheat plants caused by Soilborne wheat mosaic virus.
In April 2008, samples of wheat cultivars ORCF 101, ORCF 102, and WB528 were collected from three commercial fields in Walla Walla Co., WA with patches of wheat plants exhibiting mosaic and yellowing (Figs. 1 and 2). Samples were tested for Cereal/ Barley yellow dwarf virus, Wheat spindle streak mosaic virus, and Wheat streak mosaic virus (1); none of these viruses were found. Symptomatic plants were positive for SBWMV by ELISA (Agdia Inc., Elkhart, IN) in all three fields. Rod-shaped particles of bimodal length (140 and

$280 \mathrm{~nm}$ ) were observed under an electron microscope in partially purified virus preparations using negatively stained grids (2) indicating the presence of a furovirus (Fig. 3). To further verify SBWMV, reverse transcription polymerase chain reaction (RT-PCR) was done on total nucleic acid extracts (3) using primers specific to the SBWMV RNA-2 (2). The primer pair specific to the coat protein gene of SBWMV consisted of 5'-AAAGAGTCTIGCGTRTARCAYTC-3' and 5'-AACGGTGTTAGTAARYTRGGKGA-3') (4). RT-PCR gave an expected amplicon of ca. $300 \mathrm{bp}$ from symptomatic but not healthy plants. The amplicon was cloned and sequenced and the $338 \mathrm{bp}$ nucleotide sequence shared the highest (96\%) identity with the SBWMV sequence (accession no. L07938) in GenBank.

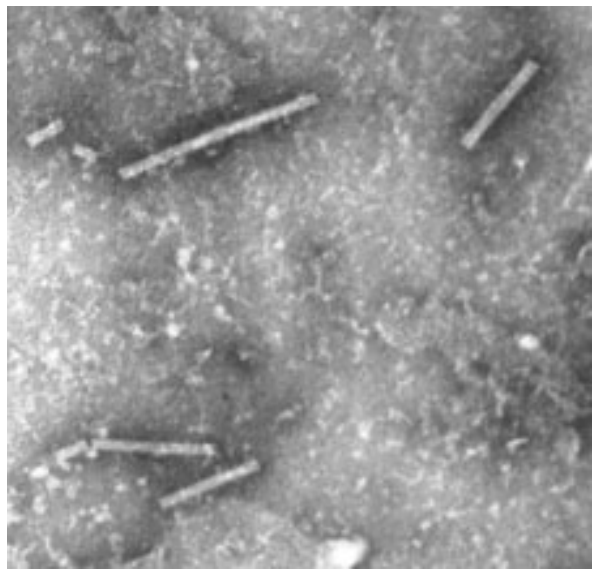

Fig. 3. Electron microscopic image of Soilborne wheat mosaic virus particles from wheat collected in Walla Walla, WA in spring 2008.

SBWMV was recently reported from an adjacent county in Oregon (4). Confirmation of SBWMV in Washington highlights the need for increased awareness of the disease and implementing measures to contain its further spread in the region. Growing disease resistant cultivars is the only practical control, but little is known about the reaction to SBWMV of wheat cultivars adapted to Washington or the variability of virus strains present in the region. 


\section{Literature Cited}

1. Deb, M., and Anderson, J . M. 2008. Development of a multiplexed PCR detection method for Barley and Cereal yellow dwarf viruses, Wheat spindle streak virus, Wheat streak mosaic virus, and Soil-borne wheat mosaic virus. J. Virol. Meth. 148:17-24.

2. Hariri, D., and Meyer, M. 2007. A new furovirus infecting barley in France closely related to the J apanese soil-borne wheat mosaic virus. Eur. J. Plant Pathol. 118:110.

3. Presting, G. G., Smith, O. P., and Brown, C. R. 1995. Resistance to potato leaf roll virus in potato plants transformed with the coat protein gene or with vector control constructs. Phytopathology 85:436-442.

4. Hamm, P. B., Gieck, S. L., and David, N. L. 2007. First report of Wheat soilborne mosaic (WSBM) on Triticum aestivum in the Columbia Basin of Oregon. Plant Dis. 91:1513. 